\title{
PERAN DUKUN DAN TUO TENGGANAI SEBAGAI MEDIATOR PESAN IMUNISASI MELALUI TRADISI "NGERAWI" DI KECAMATAN BATANG ASAI, SAROLANGUN JAMBI
}

The Role Of Dukun And Tuo Tengganai As A Mediator For Immunization Program Through "Ngerawi" Tradition In Batang Asai District, Sarolangun Jambi

\author{
Ummi Kalsum, Raden Halim, M. Ridwan
}

Prodi Kesehatan Masyarakat FKM Universitas Jambi

Kampus Pondok Meja, Jalan Tri Brata Km. 11 Mestong Kab. Muaro Jambi

Email : ummi2103@unja.ac.id

\begin{abstract}
The role of Shamans (Dukun) and Tuo Tengganai who have a respected and heardable position can be used as an excellent mediator of messenger particularly to increase community participation, especially mothers in implementing complete basic immunization for the baby. Training to improve the knowledge of Dukun and tuo tengganai is important as a first step to empowerment. The purpose of this study to assess changes in knowledge, attitude and commitment of Dukun and Tuo Tengganai as mediator of immunization messages to pregnant women and husbands, before and after the training given and the causes of low immunization coverage. The research was a quasi experiment design using one-group pre-post test design among 5 Dukun and 29 of Tuo Tengganai. Research location in Kasiro, Bukit Sulah and Datuk Nan Duo village, Batang Asai Sub District, Sarolangun Regency Jambi. There was a significant increase of knowledge after giving the training on immunization to Dukun and Tuo Tengganai as an intervention, although attitude and commitment no significantly difference after a given intervention because of the attitude and commitment already good to immunization program. Need to increase knowledge by giving training of immunization to further increase the role of Dukun and Tuo Tengganai as a messenger mediator of immunization by "ngerawi" tradition to improve infant and toddler immunization coverage.
\end{abstract}

Keywords : training, shaman, tuo tengganai, mediator, immunization

\begin{abstract}
Abstrak
Peran Dukun bayi dan Tuo Tengganai yang mempunyai kedudukan yang dihormati dan didengar dapat dijadikan mediator penyampai pesan yang sangat baik khususnya untuk meningkatkan partisipasi masyarakat terutama ibu dalam melaksanakan imunisasi dasar lengkap bagi bayinya. Pelatihan untuk meningkatkan pengetahuan dukun dan tuo tengganai penting sebagai langkah awal untuk pemberdayaan. Tujuan studi ini untuk menilai perubahan pengetahuan, sikap dan komitmen Dukun dan Tuo Tengganai sebagai mediator pesan imunisasi kepada ibu hamil dan suami sebelum dan setelah diberi pelatihan serta penyebab rendahnya cakupan imunisasi. Metode penelitian adalah intervensi dengan disain quasi eksperiment menggunakan one group pre-post test design terhadap 5 orang dukun dan 29 orang Tuo Tengganai. Lokasi penelitian di Desa Kasiro, Bukit Sulah dan Datuk Nan Duo Kecamatan Batang Asai Kabupaten Sarolangun Jambi. Ada peningkatan pengetahuan yang bermakna setelah diberikan intervensi berupa pelatihan tentang imunisasi kepada Dukun dan Tuo Tengganai, meskipun sikap dan komitmen (dukungan) tidak ada perbedaan yang bermakna setelah diberi intervensi karena sikap dan komitmen mereka relatif sudah baik terhadap program imunisasi. Perlu peningkatan pengetahuan dengan pemberian pelatihan atau penyuluhan tentang imunisasi untuk lebih meningkatkan peran dukun dan tuo tengganai sebagai mediator penyampai pesan imunisasi melalui tradisi "ngerawi"agar cakupan imunisasi bayi dan balita meningkat.
\end{abstract}

Kata Kunci : pelatihan, dukun, tuo tengganai, mediator, imunisasi 


\section{PENDAHULUAN}

Imunisasi merupakan salah satu cara efektif untuk memberikan kekebalan kepada anak terhadap penyakit tertentu, sehingga dapat menurunkan angka kesakitan, kematian serta dapat mengurangi kecacatan akibat penyakit yang dapat dicegah dengan imunisasi, serta tercapainya kekebalan komunitas (herd-immunity). Hal ini dapat terwujud bila lebih dari $80 \%$ bayi dan balita di suatu wilayah telah memperoleh imunisasi dasar lengkap (IDL) atau Universal Child Immunization (UCl) sampai tingkat desa dan dengan mutu program yang tinggi. Target pencapaian $\mathrm{UCl}$ didukung oleh Standar Pencapaian Minimum dari program imunisasi yaitu $95 \%$ dari sasaran bayi ${ }^{1}$.

Kabupaten Sarolangun adalah salah satu kabupaten di Provinsi Jambi yang cakupan imunisasinya belum mencapai target yang ditetapkan. Cakupan desa/kelurahan UCI hanya 92,8\% desa tahun 2014. Proporsi desa UCl ini bahkan menurun bila dibandingkan tahun 2013 yang sudah mencapai $94,6 \% 2$.

Hasil Riset Etnografi Kesehatan tahun 2014, cakupan imunisasi di Desa Kasiro Kecamatan Batang Asai masih rendah. Capaian imunisasi tahun 2014 adalah BCG 11\%, DPT-HB $20 \%$, Polio 4 sebesar $20 \%$ dan Campak 22\%. Meskipun meningkat namun capaian tahun 2015 juga belum mencapai target yaitu BCG $87 \%$, DPT-HB $48 \%$, Polio 4 sebesar 56,5\% dan Campak 61\%. Gambaran angka-angka capaian ini juga terjadi di beberapa desa lainnya di Kecamatan Batang Asai seperti Catuk Nan Duo dan Bukit Sulah serta beberapa desa lainnya. Hal ini menunjukkan bahwa masih banyak masyarakat yang belum mau melaksanakan imunisasi bagi bayi dan anaknya.

Peningkatan imunisasi melalui pendidikan orang tua telah menjadi strategi populer di berbagai negara. Strategi ini berasumsi bahwa anakanak tidak akan diimunisasi secara benar karena orang tua tidak mendapat penjelasan yang benar atau karena memiliki sikap yang buruk tentang imunisasi. Program imunisasi dapat berhasil bila ada usaha sungguh-sungguh dan berkesinambungan pada orang-orang yang memiliki pengetahuan dan komitmen yang tinggi terhadap imunisasi. Jika suatu program intervensi preventif seperti imunisasi ingin dijalankan secara serius, maka perlu perbaikan dalam perilaku masyarakat melalui peningkatan pengetahuan ${ }^{4}$. Perilaku seseorang juga sangat dipengaruhi oleh adat /budaya yang ada di lingkungannya.

Budaya di Desa Kasiro sebagaimana budaya Melayu Jambi di Kecamatan Batang Asai serta Kabupaten Sarolangun pada umumnya, masih sangat menghor-mati apa yang disampaikan oleh ninik-mamak dari pihak keluarganya dan sangat menghormati tokoh-tokoh adat atau sesepuh yang sering disebut dengan Tuo Tengganai di lingkungannya. Pesan atau nasehat dari Tuo Tengganai masih sangat didengar

Peran Dukun Dan Tuo Tengganai Sebagai Mediator Pesan Imunisasi Melalui Tradisi "Ngerawi" Di Kecamatan Batang Asai, Sarolangun Jambi - Ummi Kalsum, Raden Halim, 
oleh masyarakat di desa tersebut ${ }^{3}$. Kemungkinan besar peran Tuo Tengganai sebagai pemberi pesan kesehatan kepada ibu saat sedang hamil dapat lebih didengar dan dipatuhi.

Budaya lain yang masih sangat melekat adalah kepercayaan terhadap dukun bayi untuk penolong persalinan dan melaksanakan perawatan bayi. Meskipun sudah ada kemitraan antara dukun dengan bidan saat menolong persalinan, namun perawatan bayi dan ibu setelah lahir masih sangat dipercayakan kepada dukun bayi yang ada di desa. Meskipun jumlah dukun bayi semakin berkurang, namun ketergantungan dan kepercayaan terhadap dukun masih sangat tinggi. Hal ini terbukti dengan adanya budaya memberi tando ke dukun bayi di Desa Kasiro yang disebut "ngerawi" saat usia kehamilan ibu menginjak tujuh bulan ${ }^{3}$.

Hasil Riset Etnografi di Desa Kasiro menunjukkan bahwa ikatan ibu hamil dengan dukun secara kultural telah begitu kuat membudaya, meskipun sudah banyak ibu hamil yang bersalin dengan tenaga kesehatan yang ada, namun dukun bayi tidak pernah ditinggalkan. Ngerawi sendiri, hingga saat ini masih tetap dilaksanakan oleh masyarakat yang menandai usia kehamilan tujuh bulan dan tidak hanya dilakukan pada kehamilan pertama, namun pada setiap kehamilan. Budaya ini bersifat positif dan dapat diberdayakan terutama sebagai media penyampai pesan kesehatan khususnya dalam upaya meningkatkan cakupan imunisasi yang rendah di Kecamatan Batang Asai Kabupaten Sarolangun ${ }^{3}$.

Peran Dukun bayi dan Tuo Tengganai yang mempunyai kedudukan yang dihormati dan didengar dapat dijadikan mediator penyampai pesan yang efektif khususnya untuk meningkatkan partisipasi masyarakat terutama ibu dalam melaksanakan imunisasi dasar lengkap bagi bayi dan balitanya. Pelatihan untuk meningkatkan pengetahuan Dukun dan Tuo Tengganai sebagai mediator penyampai pesan imunisasi ke keluarga ibu hamil adalah penting sebagai langkah awal untuk pemberdayaan ini. Penelitian ini bertujuan menilai perubahan pengetahuan, sikap dan komitmen Dukun dan Tuo Tengganai sebagai mediator pesan imunisasi kepada ibu hamil dan suami sebelum dan sesudah diberi pelatihan melalui tradisi Ngerawi serta mencari penyebab rendahnya cakupan imunisasi di Kecamatan Batang Asai Kabupate Sarolangun Jambi.

\section{METODE}

Penelitian ini adalah penelitian intervensi menggunakan desain quasi eksperiment. Rancangan intervensi menggunakan one group pre and post test design ${ }^{8}$. Penelitian dilaksanakan di Kecamatan Batang Asai Kabupaten Sarolangun Provinsi Jambi yang berlokasi di tiga desa yaitu Kasiro, Bukit Sulah dan Datuk Nan Duo dengan kriteria belum mencapai UCl pada tahun 2015. 
Waktu Intervensi dan pengumpulan data selama 4 bulan (Mei - Agustus 2016).

Sampel penelitian adalah semua dukun bayi, kader posyandu dan Tuo Tengganai di tiga Desa lokasi penelitian berjumlah 5 orang dukun bayi dan 29 Tuo Tengganai. Dukun dan Tuo Tengganai mendapatkan pelatihan dengan modul terstruktur selama dua hari sebagai intervensi yang diberikan yang kemudian akan menyampaikan pesan melalui media budaya atau tradisi "Ngerawi" saat ibu hamil memasuki usia tujuh bulan kehamilan kepada ibu dan suaminya. Dilakukan pengukuran sebelum dan sesudah pelatihan terstruktur menggunakan kuisioner.

Variabel yang dinilai adalah pengetahuan, sikap dan komitmen terhadap program imunisasi. Pengumpulan data dilakukan dengan dua pendekatan yaitu kuantitatif dan kualitatif. Metode kualitatif dilakukan untuk mengetahui penyebab rendahnya cakupan imunisasi terhadap 20 orang informan yang terdiri dari stake holder (Kepala Puskesmas, pengelola Program imunisasi, Bidan desa, Camat, Tim Penggerak PKK dan Ketua Lembaga Adat Kecamatan sedangkan dari kelompok masyarakat terdiri dari kader, dukun, tuo tengganai dan ibu hamil).

Instrumen yang digunakan adalah : modul, lembar balik, lembar observasi, kuesioner dan kamera untuk pengumpulan data kuantitatif. Peneliti menggunakan pedoman wawancara mendalam, alat perekam, video record sebagai alat bantu yang digunakan pada pengumpulan data kualitatif. Data kuantitatif dikumpulkan menggunakan wawancara menggunakan kuisioner pada Dukun dan Tuo Tengganai yang berjumlah 34 orang serta ibu hamil dan suaminya berjumlah 39 pasang. Data kuantitatif dianalisis secara univariat dan bivariat dengan $\mathrm{Uji}$ Wilcoxon pada $\alpha=5 \%$, sedangkan data kualitatif dianalisis menggunakan Content Analysis.

Pertimbangan etik penelitian ini telah didapatkan dari Komisi Etik Badan Penelitian dan Pengembangan Kesehatan, Kementerian Kesehatan RI pada Juni tahun 2016.

\section{HASIL}

Hasil penelitian menemukan bahwa kebanyakan mediator (Tuo Tengganai) adalah laki-laki yang dalam istilah Kecamatan Batang Asai dipanggil sebagai ninik-mamak, namun Dukun bayi semuanya perempuan. Rata-rata umur mediator adalah 48,21 tahun dengan median umur adalah 49 tahun, umur termuda adalah 22 tahun sedangkan tertua adalah 80 tahun (data tidak ditampilkan). Sebagian besar mediator bekerja sebagai petani, berpendidikan relatif rendah hanya sebagian kecil saja yang berpendidikan SMA dan Perguruan Tinggi. Hampir semua menikah. Semuanya adalah asli Melayu Jambi dengan penghasilan sebagian besar $<1$ juta rupiah per bulan (tabel 1). 
Tabel 1.

Karakteristik Mediator (Dukun dan Tuo Tengganai) di Kecamatan Batang Asai, tahun $2016(n=34)$

\begin{tabular}{lrr}
\hline \multicolumn{1}{c}{ Karakteristik } & Jumlah & \\
\hline Jenis Kelamin & 23 & 69,7 \\
- Laki-laki & 10 & 30,3 \\
- Perempuan & & \\
Pekerjaan & 5 & 15,2 \\
- Wirausaha & 20 & 60,6 \\
- Petani & 1 & 3 \\
- Pedagang & 7 & 21,1 \\
- Lainnya & & \\
Pendidikan & 8 & 24,2 \\
- Tidak Sekolah/Tidak Tamat SD & 10 & 30,3 \\
- Tamat SD & 9 & 27,3 \\
- Tamat SMP & 5 & 15,2 \\
- Tamat SMA & 1 & 3 \\
- Akademi/Perguruan Tinggi & & \\
Status & 30 & 90,9 \\
- Kawin & 1 & 3 \\
- Tidak Kawin & 27 & 12,1 \\
- Duda/Janda & 4 & 6,1 \\
Suku & & \\
- Asli Melayu Jambi & 33 & \\
Penghasilan per bulan (Rp) & & \\
- <1 juta & & \\
- 1-2 juta & & \\
\hline
\end{tabular}

Tabel 2 memperlihatkan bahwa tingkat pengetahuan para mediator sebelum diberikan pelatihan tentang imunisasi, hampir semuanya kurang baik yaitu mencapai $97 \%$, namun sikap dan komitmen sudah banyak yang baik berturut-turut $64 \%$ dan $88 \%$.
Tabel 3 menunjukkan bahwa ada perbedaan rata-rata ranking skor pengetahuan sebelum dan sesudah diberi pelatihan tentang imunisasi dengan P-value $<0,05$, namun untuk nilai rata-rata sikap dan komitmen mediator terhadap program imunisasi tidak ada perbedaan yang signifikan. 
Tabel 2.

Distribusi Pengetahuan, Sikap dan Komitmen Mediator Kecamatan Batang

Asai Kab Sarolangun, Tahun $2016(n=33)$ Sebelum diberi intervensi

Pelatihan tentang Imunisasi (Pre-test)

\begin{tabular}{lcc}
\hline \multicolumn{1}{c}{ Variabel } & Jumlah & $\%$ \\
\hline $\begin{array}{l}\text { Pengetahuan } \\
\text { Kurang Baik }\end{array}$ & 32 & 97,0 \\
$\quad$ Baik & 1 & 3,0 \\
Sikap & & \\
$\quad$ Kurang Baik & 12 & 36,4 \\
$\quad$ Baik & 21 & 63,6 \\
Komitmen & & \\
$\quad$ Kurang Baik & 4 & 12,1 \\
$\quad$ Baik & 29 & 87,9 \\
\hline
\end{tabular}

Tabel 3.

Pengetahuan, Sikap dan Komitmen Mediator Sebelum dan Setelah Diberi Intervensi $(n=34)$

\begin{tabular}{lrrr}
\hline \multicolumn{1}{c}{ Variabel } & Mean-Rank & Sum of rank & P-value \\
\hline Pengetahuan & & & \\
$\quad$ Negative Ranks & 7,50 & 7,50 & $0,001^{*}$ \\
$\quad$ Positive Ranks & 15,78 & 457,50 & \\
Sikap & & & \\
$\quad$ Negative Ranks & 14,25 & 256,50 & 0,867 \\
$\quad$ Positive Ranks & 18,42 & 239,50 & \\
Komitmen & & & \\
$\quad$ Negative Ranks & 13,90 & 139,00 & 0,527 \\
$\quad$ Positive Ranks & 12,40 & 186,00 & \\
\hline
\end{tabular}

Tabel 4 memperlihatkan karakteristik informan kualitatif dimana

guruan Tinggi (35\%) serta bekerja sebagian besar informan adalah perempuan $(70 \%)$, berumur antara 20-39 tahun (50\%). Kebanyakan berpendidikan Diploma dan Persebagai PNS/Guru Honorer atau bidan, meskipun cukup banyak yang bekerja sebagai petani dan hanya mengurus rumah tangga (masingmasing $25 \%, 20 \%, 20 \%, 20 \%)$.

Tabel 4

Karakteristik Informan Kualitatif $(\mathrm{n}=\mathbf{2 0})$

\begin{tabular}{llcc}
\hline \multicolumn{1}{c}{ Karakteristik } & \multicolumn{1}{c}{ Kategori } & Jumlah & $\%$ \\
\hline \multirow{3}{*}{ Jenis Kelamin } & Laki-laki & 6 & 30 \\
\multirow{3}{*}{ Umur } & Perempuan & 14 & 70 \\
& $<20$ tahun & 1 & 5 \\
\multirow{4}{*}{ Pendidikan } & $20-39$ tahun & 10 & 50 \\
& $40-55$ tahun & 5 & 25 \\
& $>55$ tahun & 4 & 20 \\
& Perguruan Tinggi & 1 & 5 \\
& Diploma & 6 & 30 \\
\hline
\end{tabular}

Peran Dukun Dan Tuo Tengganai Sebagai Mediator Pesan Imunisasi Melalui Tradisi "Ngerawi" Di Kecamatan Batang Asai, Sarolangun Jambi - Ummi Kalsum, Raden Halim, M. Ridwan | 273 


\begin{tabular}{llll}
\hline & SMA & 4 & 20 \\
& SMP & 3 & 15 \\
SD & 3 & 15 \\
Pekerjaan & Tidak Sekolah & 3 & 15 \\
& PNS/Guru & 5 & 25 \\
& Bidan & 4 & 20 \\
& Dukun & 3 & 15 \\
& Petani & 4 & 20 \\
& IRT & 4 & 20 \\
\hline
\end{tabular}

Penyebab rendahnya imunisasi di gunakan budaya/kearifan lokal yang Kecamatan Batang Asai

Hasil wawancara mendalam dengan para informan mengidentifikasi beberapa penyebab rendahnya cakupan imunisasi yang terjadi di Kecamatan Batang Asai Kabupaten Sarolangun Jambi sebagai berikut : (1) Dukungan suami dan keluarga terhadap imunisasi dikarenakan adanya efek samping berupa demam setelah bayi atau balita diimunisasi; (2) Akses jauh karena geografis daerah, jauh dari kota kabupaten dan ketersediaan listrik hanya 6 jam serta sinyal komunikasi telepon yang sulit; (3) Ketersediaan vaksin terbatas karena penyimpanan rantai dingin (cold chain) sulit sehingga saat bayi atau balita demam atau sakit pada jadwalnya maka harus menunggu bulan depan karena vaksin tidak tersedia setiap saat; (4) Sarana dan prasarana serta dana terbatas. Hal ini yang menyebabkan pemeliharaan terhadap penyimpanan rantai dingin (cold chain) tidak dapat dilaksanakan secara kontinyu; (5) Tidak adanya pelatihan/penyuluhan yang diberikan kepada bidan desa/ kader/ masyarakat/tokoh masyarakat sebelumnya; (6) Belum ada pemberdayaan tokoh masyarakat, tokoh agama dan tokoh adat; (7) Tidak ada upaya mengada sebagai media penyampai pesan kesehatan; (8) Koordinasi dan kerjasama lintas sektor belum berjalan dengan baik dan sesuai dengan yang seharusnya.

Beberapa cuplikan pendapat dari para informan adalah sebagai berikut :

"Dikarenakan bayi setelah itu bisa demam.. jadi suami tidak mengizinkan anak untuk diimunisasi" (EA, Datuk Nan Duo, 27 Agustus 2016).

"Sering kareno kalo pas imunisasi anaknya sakit, di bulan depannya gak datang lagi. Alasannya itu kan, keno suntik tadi, demam anaknyo jadi dak mau datang lagi. Kendalanyo itulah sering disini". (Gi, Kasiro, 27 Agustus 2016)

"Ibu bayi takut kalo-kalo anak sudah imunisasi anak sakit dan suami marah karena anak sakit.." (Fit n, Desa Kasiro, 26 Agustus 2016).

"Orang tua anak minim pengetahuannyo tentang imunisasi.... kurang tau informasi manfaat.. jadi kalau demam, imunisasi besoknyo dak mau lagi datang...termos vaksin, alat lengkap tetapi SDM kurang.. Hambatan lainnya adalah listrik tidak ada dan jauh.. 4 jam dari 
rumah." (Er, Bukit Sulah, 27 Agustus 2016).

"Imunisasi yang dilaksanakan di Puskesmas Batang Asai sudah sesuai standar program disesuaikan dengan kondisi dan situasi yang ada. Vaksin cukup, peralatan cukup, SDM cukup, tapi suhu tidak maksimal yaitu hanya $2-8^{\circ}$ C. Di Kecamatan ini lampu cuma idup 6 jam dari jam 6 sore sampe jam 12 malam. Sudah itu mati sampe besoknyo lagi jam 6 sore.. Sekarang ini sudah mendingan ado solar sel untuk bantu mendinginkan vaksin di Puskesmas.. tapi kalau di Bidan Desa susah" (Dar, Batang Asai, 26 Agustus 2016).

"Vaksin tidak tepat waktu, transportasi dengan kendaraan, topografi wilayah yang menurun" (Fai, Batang Asai, 28 Agustus 2016)

"Vaksin kadang kurang dan menunggu bulan depan". (J, Kasiro, 27 Agustus 2016).

....kader tidak pernah dilatih.... (Aw, Bukit Sulah, 25 Agustus 2016).

"....Perannyo masih kurang..." (Rh, Kasiro, 27 Agustus 2016)

“...Toga dan toma tidak ada yang terlibat".. (Si, Datuk Nan Duo, 25 Agustus 2016).

"Tidak terlibat. Tokoh masyarakat dan agama tidak ikut meningkatkan program imunisasi, tapi hanya mendukung saja, tetapi tidak ikut dalam pelaksanaan." (Aw, Bukit Sulah, 25 Agustus 2016).

\section{PEMBAHASAN}

Studi ini bertujuan untuk mengetahui perubahan pengeta- huan, sikap dan komitmen mediator penyampai pesan yaitu Dukun dan Tuo Tengganai setelah diberi pelatihan tentang imunisasi dengan memanfaatkan budaya atau tradisi "ngerawi" serta mencari penyebab rendahnya cakupan imunisasi di Kecamatan Batang Asai Kabupaten Sarolangun Jambi.

Terdapat beberapa keterbatasan dan kendala dalam penelitian ini diantaranya yaitu : (1) Outcome akhir penelitian tidak dapat diukur karena efisiensi anggaran yang terjadi di Kementerian Kesehatan Republik Indonesia, sehingga penelitian ini dihentikan secara mendadak saat intervensi tahap dua sedang dilakukan yaitu kunjungan Mediator kepada lbu hamil dan pasangannya saat dilakukan tradisi Ngerawi; (2) Kendala bahasa antara tim peneliti dengan responden, khususnya dukun-dukun bayi yang sudah lanjut usia, sehingga komunikasi relatif sulit dilakukan. Solusinya adalah peneliti melibatkan koordinator lapangan setempat yang memahami bahasa daerah tersebut;

Hasil studi ini menemukan bahwa ada perbedaan rata-rata nilai pengetahuan pada Dukun dan Tuo Tengganai sebelum dan sesudah diberi pelatihan mengenai imunisasi. Namun, untuk nilai rata-rata sikap dan komitmen Dukun dan Tuo Tengganai terhadap program imunisasi tidak ada perbedaan yang signifikan. Pelatihan terstruktur bagi Dukun, Tuo Tengganai dan kader tentang imunisasi bermaksud untuk menyiapkan pemberi pesan

Peran Dukun Dan Tuo Tengganai Sebagai Mediator Pesan Imunisasi Melalui Tradisi "Ngerawi" Di Kecamatan Batang Asai, Sarolangun Jambi - Ummi Kalsum, Raden Halim, 
(mediator) yang dilaksanakan melalui budaya "Ngerawi" saat ibu hamil memasuki usia kehamilan tujuh bulan merupakan intervensi awal yang dilakukan.

Hasil studi ini menemukan bahwa sebagian besar pengetahuan mediator kurang baik sebelum diberi pelatihan. Hal ini erat kaitannya dengan rendahnya tingkat pendidikan dari mediator. Setelah diberi intervensi, tingkat pengetahuan mediator meningkat signifikan, dari hanya $3 \%$ yang mempunyai tingkat pengetahuan yang baik menjadi $64 \%$. Namun terjadi penurunan terhadap proporsi mediator yang mempunyai sikap baik dikarenakan nilai median juga meningkat dua point (hal ini menunjukkan bahwa ada pening-katan terhadap sikap) demikian pula terhadap komitmen para mediator dalam mendukung program imunisasi di desanya.

Pengetahuan merupakan hasil dari tahu dan terjadi setelah orang melakukan penginderaan terhadap suatu objek tertentu. Apabila suatu perilaku dilakukan melalui proses yang didasari oleh pengetahuan, kesadaran, dan sikap positif, maka perilaku tersebut akan bersifat langgeng. Adanya pemberian informasi melalui pelatihan atau penyuluhan merupakan salah satu upaya memberikan akses informasi kesehatan kepada masyarakat. Menurut Keleher et al, akses informasi kesehatan adalah kemampuan seseorang dalam mengetahui dan bertindak untuk mendapatkan pelayanan kesehatan yang layak. Akses informasi kesehatan diakui sebagai deteminan kunci dari kesehatan. Akses informasi adalah aktivitas warga masyarakat dalam memperoleh informasi melalui pelbagai cara, seperti melalui penyuluhan, pendidikan dan pelatihan kesehatan, media massa, media elektronika, dan lain-lain. Hal ini sesuai dengan hasil studi ini bahwa setiap akses informasi diberikan, maka akan sangat berdampak pada peningkatan pengetahuan masyarakat. Artinya segala bentuk pemberian akses informasi masih sangat dibutuhkan masyarakat, khususnya pada masyarakat perdesaan yang ratarata berpendidikan rendah dan akses informasi yang jauh, sehingga diperlukan penyuluhan atau pemberian akses informasi oleh petugas kesehatan yang berkompeten di wilayahnya masing-masing.

Hasil ini didukung juga dengan hasil studi kualitatif terhadap sikap dan komitmen Dukun dan Tuo Tengganai yang sudah baik terhadap program imunisasi. Semua informan menyatakan bahwa meskipun tidak terlibat secara aktif tokoh masyarakat, tokoh adat dan tokoh agama yang ada di Kecamatan Batang Asai ini tidak menyanggah secara frontal dan kebanyakan mempunyai sikap yang positif terhadap program imunisasi. Mereka setuju dan menyatakan bahwa program imunisasi baik dan perlu diberikan kepada bayi dan balita.

Peran Dukun bayi dan Tuo Tengganai di seluruh wilayah Keca- 
matan Batang Asai dan kebanyakan juga dalam budaya Melayu Jambi atau budaya Melayu lainnya, yang mempunyai kedudukan yang dihormati dan didengar dapat dijadikan mediator penyampai pesan yang sangat baik khususnya untuk meningkatkan partisipasi masyarakat dalam melaksanakan imunisasi dasar lengkap bagi bayi dan balitanya.

Terdapat mitos-mitos dalam Imunisasi diantaranya yaitu usia dan pendidikan orang tua dapat mempengaruhi pemberian imunisasi akibat kurangnya pemahaman terhadap imunisasi. Ketakutan atau penolakan imunisasi mungkin berdasarkan pandangan religi, filosofis tertentu. Keraguan tentang manfaat dan keamanan imunisasi perlu ditanggapi secara aktif. Apabila orang tua mendapat jawaban akurat dan informasi yang benar, maka orang tua dapat membuat keputusan yang benar tentang imunisasi ${ }^{6}$. Cara menyampaikan pesan (melalui pemberian dodol atau makanan lain yang dibagikan kepada Dukun dan Tuo Tengganai) pada tradisi Ngerawi yang dilakukan oleh Dukun dan Tuo Tengganai yang dihormati, yang masih membudaya di seluruh desa di Kecamatan Batang Asai maupun di daerah lain yang juga mempunyai adat Melayu Jambi, diharapkan dapat meningkatkan cakupan imunisasi bayi dan balita yang berdampak bagi peningkatan kese-hatan anak.

Hasil wawancara mendalam sebagaimana telah diuraikan sebelumnya mengerucut pada beberapa temuan utama sebagai penyebab rendahnya cakupan imunisasi di Kecamatan Batang Asai yaitu:

1. Dukungan suami dan keluarga terhadap imunisasi relatif rendah kepada imunisasi, dikarenakan adanya efek samping berupa demam setelah diimunisasi. Hasil ini sesuai dengan apa yang ditemukan pada Riset Etnografi di Kabupaten Sarolangun tahun 2014 pada Kecamatan yang sama. Sebagian besar informan menyata-kan bahwa dukungan suami dan keluarga menjadi faktor penyebab yang paling berpengaruh terhadap perilaku ibu dalam mengimunisasi bayi dan balitanya. Karakteristik ibu hamil dari studi ini adalah kebanyakan tidak bekerja sehingga memiliki ketergantungan secara ekonomi kepada suami. Hal itu didukung pula dengan budaya Melayu Jambi sendiri selalu memberikan tempat yang tinggi pada kedudukan suami yang sangat dihormati dan dipatuhi perintahnya, karena dalam budaya Melayu Jambi dikenal istilah bahwa adat bersendi syara' dan syara' bersendi Kitabullah (Al-Qur'an). Didalam budaya Melayu Jambi yang kental dipengaruhi agama Islam memang menempatkan kepatuhan kepada suami adalah yang paling utama dan terpenting, sehingga berdasarkan hasil studi ini, untuk peningkatan cakupan imunisasi di wilayah ini, sangat diperlukan pemberian akses informasi kepada suami sehingga suami mengerti dan memahami manfaat serta efek samping dan cara melakukan penanganan terhadap efek samping

Peran Dukun Dan Tuo Tengganai Sebagai Mediator Pesan Imunisasi Melalui Tradisi "Ngerawi" Di Kecamatan Batang Asai, Sarolangun Jambi - Ummi Kalsum, Raden Halim, 
akibat imunisasi yang ditakutkan sebagian besar masyarakat yaitu demam atau bengkak setelah diberikan imunisasi.

Tidak semua jenis imunisasi menyebabkan efek samping demam atau bengkak akibat suntikan. Namun sebagian besar masyarakat belum mengetahui, terutama para suami, yang tinggal di perdesaan dengan jenis pekerjaan berladang atau berkebun (talang) yang jauh dari akses informasi. Sehingga jenisjenis imunisasi dan manfaatnya serta efek sampingnya ini harus diperkenalkan dan dipahamkan kepada keluarga terutama suami sebagai pemegang izin bagi istri untuk membawa anaknya ke Posyandu atau ke Poskesdes untuk melakukan imunisasi. Hasil studi ini sejalan dengan hasil studi Hastono (2009) yang menemukan hubungan yang bermakna antara pendidikan ibu dan suami terhadap status imunisasi dasar pada anak berdasarkan analisis data Riskesdas 2007/2008 sehingga peneliti menyarankan perlunya Pemerintah meningkatkan pendidikan kesehatan dengan penyuluhan dan kampanye imunisasi secara tepat.

2. Akses jauh karena geografis daerah, jauh dari kota kabupaten dan pasokan listrik hanya 6 jam serta sinyal komunikasi yang sulit.

Kondisi ini adalah karakteristik spesifik lokal wilayah Kecamatan Batang Asai. Lokasi Kecamatan yang berada di daerah perbukitan dengan topografi gunung dan bukit serta merupakan wilayah kecamatan terjauh dari lbu kota Kabupaten Sarolangun menyebabkan pembangunan infrastruktur relatif lambat. Meskipun sudah ada pasokan listrik namun masih sangat terbatas, sehingga hanya tersedia selama 6 jam dari jam 18.00 sampai dengan jam 24.00 WIB setiap harinya. Hal ini pula yang menjadi kendala penyimpanan vaksin sebagai unsur utama kegiatan imunisasi. Vaksin harus disimpan dalam rantai dingin (cold chain) yang artinya sangat bergantung dengan arus listrik. Alat penyimpanan vaksin yang tersedia dan didistribusikan dari Dinas Kesehatan adalah cold chain yang membutuhkan arus listrik, saat ini tidak tersedia cold chain yang memanfaatkan tenaga lainnya seperti minyak atau gas. Oleh karenanya, pemeliharaan rantai dingin di Puskesmas menjadi mahal, sehingga vaksin dan kegiatan imunisasi hanya bisa dilakukan pada waktu yang terbatas dan rentang yang lebih pendek karena keterbatasan penyimpanan yang sangat tergantung pasokan listrik. Kegiatan imunisasi harus dapat diselesaikan oleh semua Desa pada dua minggu pertama bulan berjalan setiap bulannya, agar pemeliharaan rantai dingin tidak memakan biaya yang besar, bila dibandingkan penyediaan vaksin selama sebulan penuh. Bidan desa sendiri hanya dapat mengambil vaksin pada hari dilaksanakannya imunisasi dengan menghitung kebutuhan vaksin disesuaikan dengan jumlah sasaran yang akan diimunisasi, karena 
keterbatasan vaksin yang ada, akibat listrik yang terbatas tersebut. Hal ini mengakibatkan kesulitan bagi bayi atau balita yang tidak dapat mengikuti imunisasi sesuai jadwal karena sakit atau alasan lainnya untuk melakukan imunisasi susulan. Sehingga keterlambatan imunisasi pada bayi atau balita itu hanya dapat dilakukan pada bulan berikutnya karena tidak tersedianya vaksin setiap saat. Hal ini menjadi faktor yang sangat berpengaruh terhadap rendahnya cakupan imunisasi di Kecamatan ini, selain dukungan atau tingkat pengetahuan suami dan keluarga diatas. Jauh dan sulitnya akses ke Kecamatan ini, juga berpengaruh terhadap jumlah kunjungan untuk melakukan penyuluhan atau pelatihan kepada masyarakat dari pihak Kabupaten ataupun dari Kecamatan. Hasil analisis kualitatif menemukan bahwa meskipun sebagian besar informan menyatakan bahwa akses terhadap kegiatan imunisasi tidak terlalu jauh, namun masih ada informan yang menyatakan sulitnya topografi wilayah ini yang juga mempengaruhi rendahnya cakupan imunisasi di beberapa wilayah Desanya seperti pada ketiga desa wilayah penelitian ini yaitu Kasiro, Bukit Sulah dan Datuk Nan Duo.

3. Ketersediaan vaksin terbatas.

Karena penyimpanan sulit (cold chain) sehingga saat bayi atau balita tidak dapat imunisasi (karena demam atau sakit) pada jadwalnya maka harus menunggu bulan depan, karena ketersediaan vaksin yang terbatas akibat penyimpanan yang sulit, sebagaimana telah diuraikan pada point sebelumnya. Pihak Puskesmas hanya mampu menyimpan vaksin pada dua minggu pertama setelah vaksin diambil dari Dinas Kesehatan Kabupaten Sarolangun pada awal bulan setiap bulannya. Hasil temuan analisis kualitatif menyebutkan bahwa ketersediaan vaksin juga menjadi salah satu sebab rendahnya imunisasi di Kecamatan Batang Asai. Bagi keluarga atau suami yang sudah memahami manfaat dan efek yang ditimbulkan oleh imunisasi tertentu yang ingin melakukan imunisasi anaknya, ternyata tidak bisa dilaksanakan karena ketersediaan vaksin yang terbatas.

4. Sarana, prasarana dan dana terbatas.

Dalam suatu organisasi material dan money merupakan dua hal yang sangat berpengaruh terhadap kelangsungan suatu organisasi melakukan kegiatan. Demikian pula kegiatan imunisasi sebagai salah satu program yang harus dilaksanakan oleh Puskesmas dan jajarannya. Sarana dan prasarana yang telah diuraikan diatas memegang peranan yang penting. Demikian pula dana yang terbatas yang menyebabkan pemeliharaan cold chain (penyimpanan vaksin) juga sangat terbatas. Bila dana tidak terbatas, Puskesmas akan mampu memelihara rantai dingin sepanjang waktu sehingga ketersediaan vaksin bagi kegiatan imunisasi juga terus tersedia ketika dibutuhkan. Terba- 
tasnya mobilisasi ke Dinas Kesehatan Kabupaten ataupun kegiatan turun ke lapangan menyebabkan pembinaan dan penyuluhan kepada masyarakat tidak dapat dilakukan oleh petugas Kesehatan secara lebih sering dan kontinyu.

5. Tidak ada pelatihan/ penyuluhan yang dilakukan kepada bidan desa/kader/ masyarakat/ tokoh masyarakat.

Hasil analisis kualitatif yang telah diuraikan diatas menyebutkan bahwa penyuluhan atau pelatihan kepada bidan desa, kader atau masyarakat atau tokoh masyarakat belum dilakukan secara optimal. Sebagian besar informan masyarakat menyatakan hal ini. Hasil studi ini juga didukung oleh hasil studi kuantitatif yang telah diuraikan sebelumnya, bahwa ternyata ada peningkatan pengetahuan yang signifikan setelah pemberian pelatihan kepada masyarakat. Penyuluhan yang diberikan oleh bidan secara parsial hanya diberikan saat Posyandu dengan sasaran adalah ibu-ibu yang memang sudah memiliki kesadaran untuk datang mengimunisasikan anaknya. Sehingga lbu-ibu yang tidak datang, belum dapat dipahamkan dan diberikan akses informasi, demikian pula para suami yang memegang peran kunci terhadap keberhasilan ibu dalam membawa anaknya ke Posyandu atau Poskesdes. Tanpa izin atau dukungan suami, si lbu tidak akan berani membawa anaknya untuk diimunisasi. Hal ini yang belum dilakukan oleh petugas kesehatan yang ada baik di tingkat Kecamatan maupun tingkat desa.

6. Belum ada pemberdayaan tokoh masyarakat, tokoh agama, tokoh adat oleh stake holder kesehatan.

Temuan studi ini juga menyebutkan bahwa belum adanya pemberdayaan tokoh masyarakat, tokoh agama dan tokoh adat oleh pihak Institusi Kesehatan untuk membantu meningkatkan cakupan imunisasi atau program kesehatan lainnya. Hasil studi kuantitatif menemukan bahwa sikap dan dukungan Tuo Tengganai di wilayah ini sudah baik terhadap program imunisasi, namun karena tidak adanya pemberdayaan dan pelibatan oleh stake holder, sehingga modal sosial yang dipunyai untuk meningkatkan cakupan imunisasi tidak termanfaatkan secara maksimal. Potensi tokoh adat dan tokoh masyarakat yang mempunyai peran penting dalam budaya Melayu Jambi telah pula diuraikan pada hasil riset etnografi 2014 oleh Ismanto, et al di Kabupaten Sarolangun. Pada budaya Melayu Jambi Tuo Tengganai masih memegang peran yang penting dan dihormati. Mereka mempunyai pengaruh yang besar dalam menggerakkan masyarakat yang ada di lingkungannya. Hasil studi ini senada dengan hasil studi Sulaeman, Murti dan Waryana (2015) di Kabupaten Tulungagung Jawa Timur yang menemukan bahwa peran kepemimpinan dan modal sosial serta akses informasi kesehatan, petugas dan fasilitator 
kesehatan berpengaruh terhadap pemberdayaan masyarakat bidang kesehatan.

Penelitian Adrian menyimpulkan bahwa kepemimpinan masyarakat mempunyai peran mengikutsertakan masyarakat lokal dalam program pembangunan. Sinergi yang jelas di antara mereka untuk saling melengkapi. Dampak dari kepemimpinan masyarakat menunjukkan adanya keikutsertaan masyarakat dan menggerakkan kepemimpinan lokal yang kuat. Hal ini sesuai dengan yang ditemukan pada studi ini bahwa tokoh masyarakat baik adat maupun agama, merupakan kepemimpinan masyarakat yang mampu menggerakkan keikutsertaan masyarakat.

Penelitian Ashwell et al, menegaskan bahwa kemandirian berkelanjutan di bidang kesehatan dapat dicapai melalui kepemimpinan masyarakat dan mempertahankan aktivitas, menguatkan intervensi program dan meningkatkan interaksi antara masyarakat dan sistem kesehatan serta meningkatkan penggunaan pelayanan kesehatan oleh masyarakat termasuk pada program imunisasi.

Hasil Riset Etnografi 2014 yang dilakukan oleh Ismanto, et al menemukan bahwa masyarakat Melayu Jambi mengakui kepemimpinan masyarakat yang dikenal dengan istilah, Tengganai, Tuo Tengganai beserta Nenek Mamak yang mempunyai kewenangan untuk mengurus perihal-perihal adat yang ada di kampung. Somad (2002) menjelaskan bahwa tengganai dan nenek mamak memiliki peran sentral dalam kehidupan dan struktur sosial di masyarakat, dalam hal memecahkan persoalan dan memberikan solusi yang terjadi di masyarakat. Jenjang yang lebih luas adalah Tuo Tengganai yang mempunyai kedudukan lebih luas dibandingkan tengganai. Kewajiban Tuo Tengganai adalah mencari solusi dan meluruskan masalah adat di tingkat desa. Berdasarkan hal itu, perlu pelibatan dan pemberdayaan tokoh masyarakat, tokoh adat dan tokoh masyarakat untuk meningkatkan partisipasi masyarakat terhadap program imunisasi.

7. Belum ada upaya menggunakan budaya/kearifan lokal.

Menurut teori perubahan perilaku Lawrence Green salah satu faktor predisposisi yang mempermudah terjadinya perilaku seseorang diantaranya adalah pengetahuan, sikap, keyakinan, kepercayaan, nilai-nilai, tradisi atau budaya dan sebagainya.

Setiap masyarakat memiliki budaya, suatu rangkaian adat dan tradisi yang membawa kearah gerakan berpikir serta berperasaan sesuai dengan yang diinginkan. Budaya merupakan cara hidup manusia, fungsinya adalah menjamin kelestarian hidup dan kesejahteraan masyarakat dengan memberikan pengalaman yang teruji dalam memenuhi kebutuhan orang-orang yang tergabung dalam masyarakat yang bersangkutan. Hasil studi ini menemukan bahwa belum ada 
upaya menggunakan budaya atau kearifan lokal, khususnya di wilayah Jambi. Budaya Melayu Jambi sebagaimana telah disebutkan diatas mengakui kepemimpinan masyarakat yang mempunyai peran sentral pada beberapa tokoh adat dan pemuka masyarakat. Hasil riset etnografi di Desa Kasiro Kecamatan Batang Asai 2014 menunjukkan bahwa terdapat ikatan ibu hamil dengan dukun secara kultural yang kuat membudaya, meskipun sudah banyak ibu hamil yang bersalin dengan tenaga kesehatan yang ada, namun dukun bayi tidak pernah ditinggalkan. Dua tokoh sentral ini dapat dijadikan mediator khususnya terhadap peningkatan cakupan imunisasi.

Berdasarkan Profil Dinas Kesehatan Kabupaten Sarolangun tahun 2015, cakupan pertolongan persalinan oleh tenaga kesehatan di Kecamatan Batang Asai sudah tinggi namun cakupan imunisasinya masih rendah dan belum mencapai target yang ditetapkan. Penting untuk menyampaikan pesan imunisasi ini melalui tokoh sentral yang dihormati dan diakui sebagai pemimpin masyarakat secara adat budaya. Budaya memberikan wahana yang memungkinkan untuk terjalinnya hubungan antar personal melalui kerangka kerja terpadu antar tradisi dan adat kebiasaan. Secara naluri semua orang cenderung akan terikat pada sesuatu budaya. Hal ini juga terjadi di Kecamatan Batang Asai yang menganut Budaya Melayu Jambi yang kuat. Kepatuhan terhadap apa yang disampaikan oleh suami, keluarga (tengganai) ataupun Tuo Tengganai masih berjalan hingga saat ini. Hasil studi ini memberikan rekomendasi penggunaan budaya lokal dan kearifan yang ada seperti budaya ngerawi atau budaya lainnya untuk mendukung program atau intervensi kesehatan seperti program imunisasi.

Motivasi ternyata merupakan faktor yang sangat menentukan semua perilaku. Motivasi yang diberikan oleh tokoh penting dan sentral dapat mempengaruhi perilaku masyarakat untuk bertindak atau tidak bertindak.

8. Koordinasi dan kerjasama Lintas Sektor belum berjalan optimal. Hasil studi ini menemukan bahwa sebagian informan masih menyatakan bahwa kerjasama lintas sektor belum berjalan secara optimal. Meskipun sudah ada koordinasi yang sudah berjalan dengan baik, namun belum optimal. Camat dan Kepala Desa sebagai kepala wilayah dengan ketua tim penggerak PKK kecamatan dan desa merupakan stake holder yang berperan penting dalam penggerakan masyarakat. Diakui bahwa Camat dan Tim Penggerak PKK juga Kepala Desa sudah ikut memantau kegiatan dan program imunisasi, namun masih perlu ditingkatkan peran sertanya. Kesehatan tidak dapat dikerjakan dan diupayakan oleh Institusi atau petugas kesehatan semata, namun harus mendapat dukungan dan bantuan dari berbagai pihak dan 
stake holder lainnya. Koordinasi dan kerjasama merupakan kunci keberhasilan suatu program kesehatan, salah satunya adalah program imunisasi. Sikap tokoh masyarakat menurut teori perubahan perilaku Lawrence Green merupakan salah satu faktor penguat (reinforcing factor) yang mendorong terjadinya perilaku.

Pemberdayaan masyarakat bidang kesehatan adalah upaya atau proses untuk menumbuhkan kesadaran, kemauan dan kemampuan dalam memelihara dan meningkatkan kesehatan. Pemberdayaan masyarakat bertujuan untuk tumbuhnya kesadaran, kemauan dan kemampuan masyarakat di bidang kesehatan baik secara individu maupun kelompok?

Keadaan di lapangan menunjukkan bahwa banyak potensi masyarakat setempat yang dapat dimanfaatkan untuk kesehatan. Potensi tersebut antara lain dapat berupa pimpinan masyarakatnya, organisasi sosial kemasyarakatan, dana dan sarana masyarakat, pengetahuan dan teknologi tepat guna yang dikuasai oleh masyarakat serta potensi yang berupa kemampuan masyarakat untuk mengambil keputusan (Pranata, Pratiwi dan Rahanto, 2011).

Menurut Lawrence Green, salah satu faktor predisposisi yang mempermudah terjadinya perilaku seseorang diantaranya adalah pengetahuan, sikap, keyakinan, kepercayaan, nilai-nilai, tradisi atau budaya. Budaya Ngerawi masih dilakukan hingga saat ini di seluruh desa yang ada di wilayah Kecamatan Batang Asai, bahkan ada di seluruh Provinsi Jambi, dengan berbagai sebutan yang berbeda dan prosesi yang berbeda. Di Kecamatan Batang Asai sendiri, berbeda Desa, maka prosesi ngerawi juga berbeda. Budaya Ngerawi dilakukan untuk meminta keselamatan bagi ibu dan bayi yang ada di dalam kandungan sebagai salah satu ritual. Dilaksanakan saat memasuki usia kehamilan tujuh bulan. Di Desa Kasiro, semua kehamilan tetap dilakukan ritual ngerawi, tidak hanya kehamilan pertama saja. Namun di Desa Bukit Sulah dan Datuk Nan Duo, upacara ngerawi hanya dilakukan pada kehamilan pertama saja.

Dalam budaya ini, keluarga ibu hamil akan menyiapkan dodol hitam (jodah hitam) yang dimasak secara gotong royong, karena proses pembuatannya yang sulit dan lama dan harus diaduk secara merata diatas api selama 3-4 jam di luar rumah, dengan membuat tenda dari terpal dan dimasak secara bergantian oleh para lelaki. Bahan pembuatan dodol adalah ketan (beras sepulut), kelapa dan gula merah.

Dodol yang sudah dimasak secara bergotong royong tersebut dibungkus dengan daun pandan dan diberikan kepada dukun dengan menambahkan sirih, gambir dan potongan ayam sebagai tando (tanda). Disamping itu dodol juga akan dibagikan kepada seluruh 
masyarakat desa yang menandakan di desa tersebut ada ibu hamil berusia tujuh bulan dan akan segera melahirkan.

\section{Pemberian dodol kepada} dukun, diyakini sebagai simbol ikatan dimana si ibu hamil memberi tahu kondisi kandungannya yang sudah berumur tujuh bulan. Juga terkandung maksud bahwa si ibu sudah saatnya meminta bantuan si dukun, dan si dukun diharapkan untuk membantu dan bersedia dipanggil ketika hari persalinan telah tiba.. Sedangkan pemberian kepada masyarakat selain sebagai upaya pemberitahuan, juga meminta doa dan keselamatan dari seluruh tengganai dan msayarakat.

Tradisi ini membutuhkan dana yang cukup besar karena harus memasak bergotong royong serta membagikan jodah hitam kepada seluruh masyarakat. Namun karena rendahnya tingkat sosial ekonomi saat ini maka terdapat perubahan proses pelaksanaan ngerawi. Pemberian tando masih dilakukan kepada Dukun, Tuo Tengganai dan masyarakat namun tidak dengan proses masak-memasak bersamasama tapi hanya mengantar dalam bentuk bahan mentah yaitu ketan, kelapa dan gula merah ditambahkan ayam, sirih dan gambir ke Dukun sebagai tando usia kehamilan memasuki tujuh bulan dan akan segera melahirkan.

Meskipun karena tingkat sosial ekonomi masyarakat saat ini, terjadi pergeseran prosesi ngerawi yang dilakukan oleh masyarakat (kecuali untuk masyarakat yang mampu, masih melakukan prosesi adat ngerawi secara utuh), namun budaya Ngerawi masih tetap dilaksanakan dan menjadi adat yang masih sangat kuat, maka budaya ini dapat menjadi media atau wadah untuk menyampaikan pesan-pesan kesehatan, khususnya tentang peningkatan cakupan dan perilaku imunisasi oleh ibu dan suami bagi bayi dan balitanya.

Tokoh kunci pada budaya atau tradisi ini adalah dukun bayi yang akan terus didatangi untuk diberikan tando oleh ibu hamil dan suami. Namun Tuo Tengganai dapat menjadi mediator dengan mendatangi tengganainya yang sedang hamil untuk menyampaikan pesan dan informasi tentang imunisasi juga kepada suami ibu hamil dan keluarga lainnya. Hasil studi ini membuktikan bahwa meskipun ratarata mediator (Dukun dan Tuo Tengganai) berpendidikan rendah, namun sikap dan komitmen terhadap progran imunisasi khususnya sudah baik dan pengetahuan dapat meningkat signifikan dengan pemaparan informasi secara komprehensif.

Tokoh agama, Tokoh masyarakat, Tokoh adat masih belum dipicu untuk berdaya, namun sikap dan komitmen terhadap kesehatan sudah sangat baik dan berpotensi untuk dapat menjadi promotor kesehatan bagi desanya.

Sikap merupakan reaksi atau respons seseorang yang masih tertutup terhadap suatu stimulus atau 
objek. Sikap secara nyata menunjukkan konotasi adanya kesesuaian reaksi terhadap stimulus tertentu. Faktor-faktor yang mempengaruhi pembentukan sikap adalah7: (1) Pengalaman pribadi (apa yang telah dan sedang kita alami akan ikut membentuk dan mempengaruhi penghayatan kita terhadap stimulus sosial).

Pengaruh orang lain yang dianggap penting, (individu cenderung untuk memiliki sikap yang searah dengan sikap orang yang dianggapnya penting). (3) Pengaruh kebudayaan (kebudayaan dimana kita hidup dan dibesarkan mempunyai pengaruh besar terhadap pembentukan sikap kita). (4) Media massa (membawa pesan-pesan yang berisi sugesti yang dapat mengarahkan opini seseorang). (5) Lembaga pendidikan dan lembaga agama (Meletakkan dasar pengertian dan konsep moral dalam individu sehingga kedua lembaga ini merupakan suatu sistem yang mempunyai pengaruh dalam pembentukan sikap). (6) Pengaruh faktor emosional (suatu bentuk sikap merupakan pernyataan yang didasari oleh emosi yang berfungsi sebagai semacam penyaluran frustasi atau pengalihan bentuk mekanisme pertahanan ego. Sikap berpengaruh terhadap perilaku seseorang untuk melakukan atau tidak melakukan suatu program.

Pemberdayaan (empowering) masyarakat dalam pembangunan kesehatan sangat penting. Hal ini dapat dijelaskan bahwa : (1) Dari hasil kajian ternyata $70 \%$ sumber daya pembangunan nasional berasal kontribusi / partisipasi masyarakat; (2) Pemberdayaan masyarakat/ partisipasi masyarakat berazaskan gotong royong, merupakan budaya masyarakat Indonesia yang perlu dilestarikan; (3) Perilaku masyarakat merupakan faktor penyebab utama, terjadinya permasalahan kesehatan, oleh sebab itu masyarakat sendirilah yang dapat menyelesaikan masalah tersebut dengan pendampingan / bimbingan pemerintah; (4) Pemerintah mempunyai keter-batasan sumber daya dalam mengatasi permasalahan kesehatan yang semakin kompleks di masyarakat, sedangkan masyarakat mempunyai potensi yang cukup besar untuk dapat dimobilisasi dalam upaya pencegahan di wilayahnya;

Potensi yang dimiliki masyarakat diantaranya meliputi community leadership, community organization, community financing, community material, community knowledge, community technology, community decision making process, dalam upaya peningkatan kesehatan, potensi tersebut perlu dioptimalkan; (6) Upaya pencegahan lebih efektif dan efisien dibanding upaya pengobatan, dan masyarakat juga mempunyai kemampuan untuk melakukan upaya pencegahan apabila dilakukan upaya pemberdayaan masyarakat terutama untuk ber-Perilaku Hidup Bersih dan Sehat (PHBS).

Sejalan dengan upaya Pemerintah dalam memberdayakan dan mendorong peran serta masya- 
rakat dalam upaya kesehatan agar hidup sehat telah dikeluarkan Peraturan Menteri Kesehatan no. 65 tahun 2013 tentang pedoman pelaksanaan dan pembinaan pemberdayaan masyarakat bidang kesehatan yang dapat menjadi acuan para pemangku kepentingan dalam melakukan empowerment.

Pemberdayaan masyarakat adalah segala upaya fasilitasi yang bersifat noninstruktif, guna meningkatkan pengetahuan dan kemampuan masyarakat, agar mampu mengidentifikasi masalah yang dihadapi, potensi yang dim iliki, merencanakan dan melakukan pemecahannya dengan memanfaatkan potensi setempat.

Pemberdayaan masyarakat di bidang kesehatan adalah proses pemberian informasi kepada individu, keluarga atau kelompok (klien) secara terus menerus dan berkesinambungan mengikuti perkembangan klien, serta proses membantu klien, agar klien tersebut berubah dari tidak tahu menjadi tahu atau sadar (aspek pengetahuan atau knowledge), dari tahu menjadi mau (aspek sikap atau attitude), dan dari mau menjadi mampu melaksanakan perilaku yang diperkenalkan (aspek tindakan atau practice).

Pemberdayaan Masyarakat bidang kesehatan merupakan suatu proses aktif, dimana sasaranj klien dan masyarakat yang diberdayakan harus berperan serta aktif (berpartisipasi) dalam kegiatan dan program kesehatan. Ditinjau dari konteks pembangunan kesehatan, partisipasi masyarakat adalah keikutsertaan dan kemitraan masya-rakat dan fasilitator (pemerintah, LSM) dalam pengambilan keputusan, perencanaan, pelaksanaan, pemantauan dan penilaian kegiatan dan program kesehatan serta memperoleh manfaat dari keikutsertaannya dalam rangka membangun kemandirian masya-rakat.

Hasil studi ini mendukung pelaksanaan pemberdayaan masyarakat berbasis budaya lokal yang dapat dikembangkan untuk meningkatkan program-program kesehatan. Masyarakat menyadari sepenuhnya bahwa kekuatan mewujudkan masyarakat sehat harus dilakukan secara mandiri. Sikap dan dukungan yang baik ini hendaknya tetap dijaga dan dilestarikan oleh para pemangku kepentingan khususnya yang bergerak di bidang Kesehatan di wilayah Kecamatan Batang Asai secara khusus, Kabupaten Sarolangun dan Provinsi Jambi secara umum.

Untuk mempertahankan kesinambungan intervensi yang telah dilaksanakan oleh Tim Peneliti, maka telah disusun modul pembelajar dan leaflet berbahasa daerah yang diberikan kepada setiap mediator. Leaflet dapat dijadikan pedoman atau dapat pula diberikan kepada pasangan agar pasangan paham dan mengerti program imunisasi sehingga mau mengimunisasikan anaknya. Diharapkan apa yang sudah dilakukan dapat dilanjutkan oleh masyarakat bersama-sama stake holder yang ada di Kecamatan 
Batang Asai Kabupaten Sarolangun dengan tujuan akhir masyarakat hidup sehat.

\section{KESIMPULAN}

Dari uraian tersebut, dapat disimpulkan bahwa pelatihan yang diberikan kepada mediator (Dukun dan Tuo Tengganai) mengenai informasi terkait program imunisasi telah memberikan peningkatan pengetahuan menjadi lebih baik. Namun sikap dan komitmen yang pada awalnya sudah baik dapat diberdayakan dan menjalankan peran sebagai mediator penyampai pesan imunisasi melalui budaya "Ngerawi" saat ibu hamil memasuki usia kehamilan tujuh bulan.

\section{SARAN}

1. Perlu dukungan, perhatian dan pembinaan secara berkelanjutan dari sektor kesehatan maupun di luar sektor kesehatan untuk lebih meningkatkan peran dukun dan tuo tengganai sebagai mediator penyampai pesan imunisasi guna mendukung upaya peningkatan cakupan imunisasi bayi dan balita yang berdampak bagi peningkatan kesehatan anak.

2. Masih dibutuhkan kesinambungan peningkatan pengetahuan dengan pemberian pelatihan atau penyuluhan tentang imunisasi untuk lebih meningkatkan peran dukun dan tuo tengganai sebagai modal sosial yang dapat mendukung program kesehatan khususnya imunisasi.

\section{UCAPAN TERIMA KASIH}

Ucapan terima kasih kepada Pusat Humaniora Kebijakan Kesehatan dan na Masyarakat Badan Penelitian dan Pengem-bangan Kesehatan Kementerian Kesehatan Republik Indonesia yang telah mendanai penelitian ini. Penghargaan yang tinggi juga kami sampaikan kepada Dekan dan civitas akademika FKIK, khususnya program studi kesehatan masyarakat atas semua dukungan dan partisipasinya. Ucapan terima kasih juga disampaikan untuk Camat, Kepala Puskesmas Batang Asai dan jajarannya yang telah memfasilitasi dengan baik kegiatan penelitian ini.

\section{DAFTAR PUSTAKA}

Dinas Kesehatan Provinsi Jambi. 2013. Modul Pelatihan Peningkatan Kapasitas Petugas Imunisasi Kabupaten dan Puskesmas Dalam Provinsi Jambi Tahun 2013. Jambi : Dinas Kesehatan Provinsi Jambi.(1)

Dinas Kesehatan Kabupaten Sarolangun. Profil Kesehatan Sarolangun Tahun 2013. Jambi : Dinkes Sarolangun Provinsi Jambi.(2)

Ismanto, $\mathrm{M}$, Peudada $\mathrm{H}$, Yanti I dan Budisuari MA. 2014. Buku Seri Riset Etnografi Kesehatan 2014. Nun Jauh di mudik Buruk Kelaku Budak. Etnik Melayu JambiKabupaten Sarolangun. Jakarta : Lembaga Penerbitan Balitbangkes Kementerian Kesehatan RI.(3) 
Ali, Muhammad. 2002. Pengetahuan, Sikap dan Perilaku lbu Bekerja dan Tidak Bekerja tentang Imunisasi. Diakses dari

http://library.usu.ac.id/modules .pkp.op=modload tanggal 16 Januari 2016.(4)

Proverawati, Atikah.2010.Imunisasi dan aksinasi.Yogyakarta:Nuha Offset.(5)

IDAI. 2008.Pedoman Imunisasi Di Indonesia.Jakarta:Satgas Imunisasi.(6)

Notoatmodjo, Soekidjo, 2007.Promosi Kesehatan dan Ilmu Perilaku. Jakarta: Rineka Cipta.(7)

Kementerian Kesehatan Republik Indonesia. 2013. Peraturan Menteri Kesehatan nomor 65 tahun 2013 tentang Pedoman Pelaksanaan dan Pembinaan Pemberdayaan masyarakat bidang kesehatan.(8)

Murti, Bhisma, 1997. Prinsip dan Metode Riset Epidemiologi. Yogyakarta : Gajah Mada University Press.(9)

Hastono, SP. 2006. Analisis Data. Jakarta : Fakultas Kesehatan Masyarakat Universitas Indonesia.(10)

Departemen Kesehatan Republik Indonesia.2005. Kemitraan : Pusat Promosi Kesehatan. Diakses dari www.promkes.go.id , tanggal 23 November 2016. (11)

Maulana, Heri , 2009. Promosi Kesehatan. Jakarta : EGC. (12)

Hastono SP. 2009. Analisis Data Riskesdas 2007/2008 : Kontribusi Karakteristik lbu terhadap Status Imunisasi Anak di Indonesia. Jurnal Kesehatan Masyarakat
Nasional Volume 4. Nomor 2, Oktober 2009. (13)

Sulaeman, Murti dan Waryana. 2015. Peran Kepemimpinan, Modal Sosial, Akses Informasi serta Petugas dan Fasilitator Kesehatan dalam Pemberdayaan Masyarakat Bidang Kesehatan. Jurnal Kesehatan Masyarakat Nasional Volume 4. Nomor 2, Oktober 2009.(14)

Adrian M. 2010. The community leadership and place-shaping roles of english local government synergy or tension? Public Policy and Administration. 2010; 25 (5): 175-87.9(15)

Ferguson KM, Kim MA, McCoy S. 2011. Enhancing empowerment and lead ership among homeless youth in agency and community settings: a grounded theory approach. Child Adolescence Social Worker Journal. 2011; 28 (4):1-22. (16)

Pitts DW. 2005. Leadership, empowerment, and public organizations. Review of Public

Personnel

Administration. 2005; 25 (3): 5-17. (17)

Keleher H, Mac DC. 2009. Understanding health a determinants approach. 2nd Edition. Australia and New Zealand: Oxford University Press; 2009. (18)

Fineberg H. 2004. Health literacy, Institute of Medicine. The National Academics Press; 2004.(19)

Ashwell HES, Barclay L. 2009. A retrospective analysis of a community-based health program in Papua New 
Guinea. Health Promotion International. 2009; 24 (2): 140-148.(20)

Pranata S, Pratiwi NL dan Rahanto S. 2011. Pemberdayaan Masyarakat di Bidang Kesehatan, Gambaran peran kader Posyandu dalam upaya penurunan Angka Kematian dan Bayi di Kota Manado dan Palangkaraya. Buletin Penelitian Sistem Kesehatan, Volume 14 Nomor : 2 April 2011 : 174-182. (21) 